\title{
Organizational Contact Type Code
}

National Cancer Institute

\section{Source}

National Cancer Institute. Organizational Contact Type Code. NCI Thesaurus. Code C93883.

A coded value specifying the kind of organizational contact. 